\title{
From Quest to Conquer: Traversing General Education at a Diverse Alaskan University to Integrate and Assess Transferable Information Literacy Skills in Foundational Courses
}

\author{
Anna Bjartmarsdóttir* and Deborah l. Mole \\ University of Alaska Anchorage
}

\begin{abstract}
The University of Alaska Anchorage (UAA) is an open enrollment university that offers vocational, academic, and professional degrees in a northern region. UAA serves a culturally and demographically diverse population. Given this diversity, students display varying levels of information literacy (IL) competencies. Library Professors Anna Bjartmarsdóttir and Deborah Mole partner with faculty teaching composition and communication courses to create increasingly sophisticated and transferable IL learning opportunities. Strategies include: assessing students' IL competencies; creating engaging activities; integrating IL throughout the semester; developing reflection opportunities to reinforce IL skills. UAA librarians, partnered with faculty, integrate and scaffold IL activities in foundational GE courses to develop increasingly sophisticated, transferable IL skills and knowledge practices. From team-based learning application exercises to workshops for teaching assistants, students learn how creativity partnered with initiative has helped to integrate transferable IL skill education at this diverse arctic university.
\end{abstract}

Keywords: information literacy, assessment

\author{
*Contact: \\ Anna Bjartmarsdóttir \\ University of Alaska Anchorage \\ E-mail: abjartmarsdottir@uaa.alaska.edu
}




\section{Background}

According to the UAA 2014/15 Fact Book, in 2014, 6,022 full-time students and 8,732 part-time students attended UAA Anchorage courses. Of the 14,754 students attending UAA, the majority are nontraditional, and less than half are enrolled full-time. Since UAA is an open enrollment university, there are students at a wide range of academic levels; many are attending college while working and raising a family. To serve Alaska's needs, UAA offers a wide range of degrees from vocational and technical to doctoral-level; offering courses electronically and on site; most at the undergraduate level. All of these factors contribute to the challenge of assuring that all students achieve the general education (GE) outcomes promised by the university.

A 2014 GE faculty survey revealed that faculty consider information literacy a priority, second only to communication. With IL a GE learning outcome priority, teaching IL skills for retention and transferability is crucial. One of UAA's GE outcomes states that students will be able to: "Locate and use relevant information to make appropriate personal and professional decisions." In GE courses like the Fundamentals of Oral Communication (COMM 111) and Introduction to Written Composition (ENGL 111), it is essential for students to gain a strong foundation of information literacy skills that prepare them for success in other academic courses. Professors Deborah Mole and Anna Bjartmarsdóttir, the Consortium Library's liaisons to the Journalism and Communication and English Departments, have collaborated with faculty to integrate information literacy skill-building activities and assessments into the foundational COMM 111 and ENGL 111 courses, so that skills can be transferred not only to academic, but also personal, professional, and civic situations. This paper will outline collaborative IL initiatives in UAA's GE program, the evolution of teaching practices, and the results of these efforts.

\section{Engaging Librarians and Faculty in Information Literacy Initiatives}

With the internet as the first place most people begin research, Information literacy has evolved as a noticeable challenge for many students conducting academic research. UAA faculty have complained of students citing about.com, Wikipedia, and Google. As faculty voiced IL concerns, librarians evolved IL teaching practices and outreach efforts. Embedded collaboration between faculty and librarians began to increase IL awareness and enhance student learning. Following are key points in the collaborative development between GE faculty and liaison librarians to improve students' IL skills.

In 2011, Professor Mole attended ACRL's Assessment Immersion training, and applied for UAA to participate in the Rubric Assessment of Information Literacy Skills (RAILS) project lead by Syracuse University professor Megan Oakleaf. In 2012, a combination of ten faculty members, including subject faculty, librarians, and an administrator, gathered to norm and assess 100 student artifacts from Western Civilization and Art Appreciation courses for three IL student learning outcomes (SLOs). Faculty from the Communication and English Departments participated. In 2012, Professor Mole also initiated an Information Literacy Interest Group to promote conversation around IL.

\section{Developing Information Literacy Collaboration}

In 2013, an initiative to integrate information literacy into course curriculum was introduced at the university. Led by a faculty librarian, the Center for Advancing Faculty Excellence (CAFE) offered an iPad Mini to instructors who worked with liaison librarians to integrate information literacy into their course curriculum. As part of this project, Professor Bjartmarsdóttir partnered with English professor and Composition Program Director, Jackie Cason, to integrate information literacy development into the Introduction to Written Composition (ENGL 111) course. The results of the ENGL 111 Mini grant included a LibGuide with IL assignments. Professor Mole, partnering with Communication professor Shawnalee Whitney, also received a 
Mini grant to integrate information literacy into the Fundamentals of Oral Communication (COMM 111) course. The product of this Mini grant was a LibGuide defining the process, activities and assessments used in integrating information literacy into COMM 111. Grant recipients also had to formally present their project at a CAFE event. By spring 2015, CAFE also hosted an information literacy summit to develop additional faculty and librarian partnerships and IL integration strategies.

\section{Information Literacy and Written Composition}

Anna Bjartmarsdóttir serves as the Consortium Library's liaison to the English Department, the department responsible for teaching the foundational composition courses and other writing and literature courses. Introduction to Written Composition (ENGL 111) is taught by professors and graduate teaching assistants (TAs). The Libguide created by Professors Bjartmarsdóttir and Cason for the Mini grant is available to inform and support these instructors teaching information literacy skills in their courses, seeking to move teachers and students beyond the genre of "the research paper" toward an understanding of inquiry as embedded in all writing assignments. The content of the guide is continually updated and improved upon. In addition, Professor Bjartmarsdóttir has worked closely with the professor who trains the TAs to assure they are knowledgeable about resources and services available to students, and the information literacy instruction offered by library faculty.

Professors Cason and Bjartmarsdóttir also initiated a study to compare the Association of College and Research Libraries, ACRL Information Literacy Framework with Naming What We Know: Threshold Concepts of Writing Studies. Professor Cason proceeded with a sabbatical project, studying the two documents, with the assistance of Professor Bjartmarsdóttir. She consulted with Professor Bjartmarsdóttir on a weekly basis, discussing the two documents and ultimately focusing on three threshold concepts in each document. Professor Cason wrote, "We have found a way to describe the inherent relationship between writing and information literacy based on the threshold concept frameworks of our respective disciplines" (Cason, 2016).

The table below shows three ACRL IL Framework threshold concepts and three Writing Framework threshold concepts, side by side, followed by three Integrative Bridges.

\begin{tabular}{|l|l|l|}
\hline ACRL IL Framework & Naming What We Know & Integrative Bridge \\
\hline Research as Conversation & $\begin{array}{l}\text { Writing is a Social and } \\
\text { Rhetorical Activity }\end{array}$ & Social Drama \\
\hline $\begin{array}{l}\text { Information Creation as a } \\
\text { Process }\end{array}$ & $\begin{array}{l}\text { Writing Speaks to Situations } \\
\text { through Recognizable Forms }\end{array}$ & Meaningful Design \\
\hline $\begin{array}{l}\text { Authority is Constructed and } \\
\text { Contextual }\end{array}$ & $\begin{array}{l}\text { Writing enacts and creates } \\
\text { identities and ideologies }\end{array}$ & Credibility in Community \\
\hline
\end{tabular}

Learning outcomes were additionally created for each of the bridges. Professor Cason created the language to describe those outcomes, after careful consultation with Professor Bjartmarsdóttir. The Bridge, Social Drama, has been assigned to the outcome, "Students will be able to identify an issue and its relevance to an established audience, engage divergent perspectives on that issue, and contribute to an ongoing conversation." The Bridge, Meaningful Design, has been assigned to the outcome, "Students will be able to recognize the meaningful relationship between writing processes and products and adopt formal structures appropriate 
to the situation." Finally, for the Bridge, Credibility in Community, was given the outcome, "Students will be able to assess and establish credibility and persuasive power within the context of a particular community's norms for accuracy, relevance, evidence, and argument" (Cason, 2016). The next step will be to create learning activities based on the outcomes, with the goal that discipline faculty across the university can choose from a suite of student learning activities tied to each of these outcomes.

The fundamental idea behind this project is that writing and research are interconnected and necessary in all areas of study. Therefore, it makes sense to integrate them, instead of to look at them separately as unrelated skills that can be mastered individually and autonomously.

\section{Information Literacy and the Fundamentals of Oral Communication}

Deborah Mole has been providing library research instruction to the Fundamentals of Oral Communications classes taught by professor Shawnalee Whitney for more than six years. During these sessions, the focus had been on preparing students for their presentation assignment. Initially, Professor Whitney's speech assignments required students to research and present about nonprofit organizations. Library instruction was delivered as a lecture.

Assessment included an information literacy survey and observation of students' involvement and success in searching for sources and citing them appropriately.

The Mini-grant opportunity motivated Professors Whitney and Mole to become creative and intentional about the inclusion and reinforcement of information literacy skills throughout the semester. For example, conversations about information bias became part of a classroom discussion around perceptions. Students also completed a survey before the library session that included IL application and confidence questions; and later in the semester students completed a survey to assess IL improvement and library session value. As Professors Whitney and Mole have developed knowledge of Team-Based Learning (TBL) through professional development opportunities, TBL techniques have been used to engage students in team activities around identifying credible and scholarly sources. Speech assignments in Professor Whitney's classes have evolved into team projects, with each member presenting on a different facet of the organization or issue. The research process thus includes conversation and engagement prior to searching for information.

As this partnership evolved, additional Communication faculty joined in to collaborate on assessment and integration of information literacy. Routine meetings with Communications faculty ignited an evolution around IL instruction. Strategies for developing high impact learning practices that inspire transferability of IL skills have become the priority. According to Perkins and Salomon, "Proper attention to transfer will make the best of both [general and local knowledge] for the sake of deeper and broader knowledge, skill, and understanding"(p. 31). Instead of overloading and boring students with a lecture, key outcomes have been identified and learning activities created. Following are typical activities included in a library session:

1. Website evaluation: In teams, students identify a minimum of three criteria used to distinguish if a website is credible. They list them on the whiteboard. Library faculty and/or instructor lead class in identifying similarities and gaps.

2. Scholarly vs trade publications: Teams of two or three students compare a paper copy of a trade magazine and a scholarly journal. They are asked to find the editors (the role of editor may need to be explained), identify the differences, and identify the audience for each publication. Teams report to the class, or there is a class discussion.

3. Brainstorming search terms: Students create a bubble map of search terms, then hand their bubble map(s) over to another classmate, who adds on to their bubble map. Instructors often ask students to prepare a bubble map in advance of the library session 
to save time. When students read what another student has added to their bubble map, they discover the value in other perspectives.

4. Search tools: Students learn about expanding and narrowing search results using wildcard symbols, phrase searching, and Boolean operators.

5. Research time: Students are introduced to library databases (including limiting and saving features), and search for articles, books, dissertations, and more.

Additionally, there has been effort by the instructors to incorporate activities that reinforce information literacy throughout the semester. Some faculty include real world scenario assignments, and service projects that include preparatory research. Following is one example of an in-class TBL application exercise used in COMM A111:

\begin{abstract}
Green fee funding is available to university students to use toward a project that helps the environment. Teams are tasked with creating an argument to use the university's Green Fee funding to develop an organic garden on campus. Teams decide on the argument (environmental, social, emotional, physical, or financial benefit), and then find three sources of evidence to support that argument. They present their argument with supporting evidence, and the justification for the sources selected.
\end{abstract}

A question asked in a worksheet for this TBL application exercise is, "Who would be the authority on this topic?" This question asks students to reflect on how authority is subjectdependent. It aligns well with the ACRL IL Framework frame, Authority is Constructed and Contextual.

\title{
Next Steps
}

As a result of collaboration with Communications and English faculty, Library Professors Bjartmarsdóttir and Mole have observed an evolution in the conversation around IL. Faculty are exploring IL frameworks, and evolving classroom activities to develop students' IL habits of mind. There is the realization that students in GE courses need building blocks to achieve the information literacy skills faculty expect in upper division courses. Professors Bjartmarsdóttir and Mole strive to create these building blocks through the development of clear, attainable SLOs, high impact learning practices, research reflection assignments, and real world application exercises. In ENGL 111, interwoven IL and writing outcomes are created to enhance students' research and writing success. In COMM 111, faculty and librarian partnerships work to teach and assess IL skills for transferability to other courses and situations. From bridging IL and writing frameworks to developing high impact learning practices, the student-centric efforts of these GE faculty/librarian partnerships has taken its hold on improving IL skills and habits of mind. With these continued efforts toward IL integration, students will achieve information literacy skills that transfer to personal, professional, and civic situations. 


\section{References}

Association of College and Research Libraries. (2016). Framework for Information Literacy for Higher Education. Retrieved from http://www.ala.org/acrl/standards/ilframework

Bjartmarsdóttir, A., \& Cason, J. (2013). English 111 -- Introduction to Composition. [LibGuide]. Retrieved from http://libguides.consortiumlibrary.org/c.php?g=488935

Cason, J.E. \& Bjartmarsdóttir, A. (2016). Unbounded, discursive, integrated: Bridging threshold concepts for writing and information literacy to foster development and account for expertise [Prezi]. Retrieved from http://prezi.com/spafhp9mkrdj/?utm_campaign=share\&utm_medium=copy

General Education Requirements for Baccalaureate Degrees. (2015). 2015-2016 Catalog,University of Alaska Anchorage. Retrieved from https://catalog.uaa.alaska.edu/undergraduateprograms/baccalaureaterequirements/ge rs/?ref=driverlayer.com

Mole, D., \& Whitney, S. (2013). COMM A111 - Information Literacy Integration: Project Overview. [LibGuide]. Retrieved from http://libguides.consortiumlibrary.org/COMM111InfoLit

Office of Institutional Research, University of Alaska Anchorage. (2015). Fact Book 2014-15. Retrieved from https://ir-reports.uaa.alaska.edu.

Perkins, D.N., \& Salomon, G. (1988) Teaching to transfer. Educational Leadership. 4(1), 22-32. 